Research Paper: Research Proposal

\title{
Applying of Fatwa in the Case of Islamic Banking in Court: A Study of the Development of Islamic Banking in Indonesia
}

\section{Andi Wahyudin Jalil ${ }^{1}$, Achmad Yani ${ }^{1}$}

${ }^{1}$ Faculty of Social Sciences, Univerisit Sains Malaysia. Penang, Malaysia.

Article History

Received:

16.08.2021

Revised:

02.09.2021

Accepted:

22.09.2021

*Corresponding Author:

Achmad Yani

Email:

achmad.yani@student.usm.my

This is an open access article, licensed under: $\mathrm{CC}-\mathrm{BY}-\mathrm{SA}$
Abstract: This research generally aims to examine the things that need to be considered in advancing Islamic banking. The research method used to achieve the research objectives is a qualitative research design with a research strategy through case analysis, data collection methods in interviews, and data analysis methods in analytical content. This study recommends how the Islamic banking in expanding the Islamic banking market. Based on the research, in general, there are 3 main agendas that need attention in advancing Islamic banking, namely national policy support, expansion of Islamic economic and financial institutions, and the last is education and inculcation of Islamic economic values and concepts.

Keywords: Court Decision, Fatwa, Islamic Banking Institution. 


\section{Introduction}

Development in Islam is development that encompasses physical (material) and spiritual development (including the mind). Islamic economic development is part of Islamic development [1]. The concept of Islamic economic development is a concept that studies and analyzes the development process, the factors that influence it, and identifies and recommends development policies based on the Qur'an and Sunnah of the Prophet Muhammad [2]. Man is the main focus in the process of Islamic economic development. This is because in economic development, human economic activity is not only to satisfy oneself to physical needs, but even man has a duty and responsibility to his Creator. Thus, morality and spirituality are part of the development process that runs holistically [3].

Economic development in most countries that are majority Muslim and have a very large source of natural wealth today is seen as still backwards in economic development. For example, Islamic countries that are members of the Organization of Islamic Cooperation (OIC), economic growth in these countries is still at a low level compared to developed countries. About 27.2 percent of the total population is still living on per capita incomes below $\$ 1.25$ a day. Asserts that economic development unfounded by Islamic principles (capitalism and socialism) has failed in exhibiting justice in the economy [4].

One of the causes of economic development failures in developing countries is due to the abandonment of development instruments that are in accordance with local religion and culture. Thus improvements should continue to be made by paying attention to development that is in line with local religious and cultural values and in parallel with the Qur'an and Sunnah in various sectors of the economy [5].

One of the most important sectors that need to be paid attention in the development of Islamic economy is the development of Islamic banking. This is because financial institutions and banking activities play a very important role in driving the development of a country [6]. In fact, banking is also one ofthe agents of development (agent of development). Currently, the development of Islamic banking in the developing country is seen to continue to grow rapidly in parallel with the increase of investors from the Middle East country and they are certainly committed in practicing Islamic values in economic activities [7]. Islamic economic and banking growth is expected to form synergies in strengthening the economic structure and financial markets of the world in the present and future [8]. Today, approximately 75 countries in the world have applied the Islamic economic and financial system, whether in Asia, Europe, America or Australia [9]. In Middle Eastern countries in particular and Asia in general, more and more proactive efforts are being made to develop Islamic banking and finance. Even Islamic banking institutions also strive to cooperate with corporate companies in western countries and Europe in an effort to promote Islamic banking and finance in the region [10].

The Islamic banking system is different from the conventional banking system, as the Islamic financial and banking systems are subsystems of an Islamic economic system with a broader scope. Therefore, Islamic banking is not solely aimed at generating profits; but it also demands to showcase the implementation of Islamic values. This distinguishes it from conventional banking which is only profit-motivated [11]. In conventional banking there are elements prohibited by Islamic sharia, such as receiving and paying interest (riba), financing the production and trade of prohibited goods such as wine (haram), activities very close to gambling(maisir)for certain transactions in foreign exchange dealing, and highly and intended speculative transactions (gharar)in banking investments [12].

In Indonesia the development of Islamic banking is now one of the drivers of economic development in Indonesia [13]. Relating to Islamic banking, there are two models of Islamic banking in Indonesia: Sharia Commercial Bank and Sharia People's Financing Bank. Bank general Syariah is an Islamic bank involved in payment transactions while the Islamic People's Financing Bank is an Islamic bank that is only related to financing. In summary in Indonesia, the banking system in the country uses a dual banking system model that practices twin banking involving conventional and Islamic banking models.

The development of the Islamic banking system in Indonesia occurred in the form of the demand of the Islamic community who believed that the benefits received from conventional banking were a transaction prohibited by religion [14]. Therefore, Bank Muamalat was established in 1991, which also became the beginning of the development of Islamic banking economy in Indonesia [15]. The general development of Islamic economics and the development of Islamic banking in particular continued to grow after the Fatwa of the Indonesian Ulema Council (MUI) at the end of 2003, which 
declared the law of illegal benefits of conventional banks. As a result, the Islamic community began to abandon transaction affairs with conventional banks [16].

The Financial Services Authority (OJK) is an institution established concerning the Financial Services Authority (UU OJK). The institute was established to conduct integrated supervision of the financial services industry. According to the provisions of Article 1 number 1 of the OJK Law, it is formulated that OJK is an institution that has freedom that is free from interference from the interference of other parties, which has the function, duties, and regulations, supervision, examination, and investigation [17].

OJK was formed with the aim that all activities in the financial services sector can be carried out regularly, fairly, openly and responsibly, able to create a financial system that grows sustainably and stable, and is able to protect the interests of consumers and society, which is realized through an integrated regulatory and supervision system of all activities in the financial sector [18]. The function of OJK is determined in Article 5 of the OJK Law, namely OJK serves to carry out an integrated regulatory and supervisory system of all activities in the financial sector. OJK carries out regulatory and supervisory duties on:

(1) Financial sector activities in the banking sector

(2) Financial sector activities in the capital market sector

(3) Financial sector activities in the insurance sector, retirement funds, financing institutions, and other financial sector institutions.

The competence of OJK is determined in Article 7 of the OJK Law, which reads that in carrying out its duties, OJK has the following information: a. Arrangements and supervision regarding bank institutions which include:

(1) Permits for the establishment of banks, opening bank officials, articles of association, work plans, ownership, management and human resources, mergers and takeovers of banks, and the revocation of bank business licenses; and

(2) Bank business activities, including but not limited to funding sources, funding provision, hybrid products, and activities in the service sector;

In addition, OJK is also an institution of regulation and supervision regarding bank stability, which includes:

(1) Liquidity, profit, solvability, asset quality, minimum capital adequacy ratio, maximum loan limit, loan ratio to deposits, and bank reserves

(2) Bank statements relating to the health and performance of the bank

(3) The debtor's information system

(4) Credit test

(5) The standard of bank accounting.

OJK also conducts arrangements and supervision on aspects of bank prudence, including:

(1) Risk management

(2) Bank governance

(3) Principles regarding customers and anti-money laundering

(4) Prevention of financing of terrorism and banking crimes.

In Indonesia, the development of Islamic banking is seen from an increase in the number of assets that increases from year to year. Data cited from the Financial Services Authority (OJK) (2015) showed the amount of Islamic banking assets was Rp. 213.42 billion and increased to Rp. 316.69 billion in December 2018.

OJK also conducts arrangements and supervision on aspects of bank prudence, including:

(1) Risk management

(2) Bank governance

(3) Principles regarding customers and anti-money laundering

(4) Prevention of financing of terrorism and banking crimes. 
Table 1. Development of Total Assets, Networks of Officials and Islamic Banking Workforce

\begin{tabular}{lcccc}
\hline \multicolumn{1}{c}{ Indikator } & $\mathbf{2 0 1 5}$ & $\mathbf{2 0 1 6}$ & $\mathbf{2 0 1 7}$ & $\mathbf{2 0 1 8}$ \\
\hline Sharia Commercial Banks (BUS) & \multicolumn{4}{c}{} \\
\hline Total banking assets & 213,423 & 254,184 & 288,027 & 316,691 \\
\hline Number of banking companies & 19 & 13 & 13 & 14 \\
\hline Number of banking company officials & 1,990 & 1,869 & 1,825 & 1,875 \\
\hline Number of banking workers & 51,413 & 51,110 & 51,068 & 49,516 \\
\hline Sharia Business Unit (UUS) & \multicolumn{5}{c}{} \\
\hline Total banking assets & 82,839 & 102,320 & 138,154 & 160,636 \\
\hline Number of banking companies & 22 & 21 & 21 & 20 \\
\hline Number of banking company officials & 311 & 332 & 344 & 354 \\
\hline Number of banking workers & 4,403 & 4,487 & 4,678 & 4,955 \\
\hline Total assets of BUS and UUS & $\mathbf{2 9 6 , 2 6 2}$ & $\mathbf{3 5 6 , 5 0 4}$ & $\mathbf{4 2 4 , 1 8 1}$ & $\mathbf{4 7 7 , 3 2 7}$ \\
\hline Number of banking companies & 41 & 34 & 34 & 34 \\
\hline Number of officials & 2,301 & 2,201 & 2,169 & 2,229 \\
\hline Total manpower & 55,816 & 55,597 & 55,746 & 54,471 \\
\hline
\end{tabular}

The growth of Islamic banks has seen an increase in the number of customers every year. At the same time, this increase also resulted in an increase in the number of cases related to Islamic banking in the courts. The type of Islamic banking case that arises usually involves such as musyarakah financing and Murabahah financing case. According to a report by Badilag MARI (Supreme Court Religious Justice Agency) in December 2015, the case of Islamic banking registered with the court at the national level was 6 cases which then increased to 12 cases in January 2016 [19].

Most settlements of Islamic banking cases are through two ways, namely through public and external courts involvingpeer-weight bodies (arbitration) [20]. In the Court, judges are seen as appropriately using an approach based on Islamic principles in talking about Islamic economic cases including Islamic banking. Thus, the principles of Islam should be the most important foundation to be understood. This is because, formal laws and material laws that are drafted today do not fully enforce and protect Islamic material laws. For example, in terms of the settlement of Islamic banking, [21]. The Islam has outlined an ideal concept for resolving the case that exists among humans that covers various aspects of life. If this is not done, it can lead to injustice.

Banking is the most important financial institution in carrying out economic activities. In the perspective of modern economics, banking facilitates exchange and helps the formation of capital and production in large quantities. Likewise Islamic banking, its increasingly advanced growth and development is seen to help and support economic development in Indonesia. Islamic banking relations in supporting Indonesia's economic development can be seen more clearly through the increasing number of people who use Islamic banking [22].

In discussing the case of Islamic banking, the principle of freedom of judgment can apply that judges are free to make choices in case decisions [23]. However, the judge also referred to the MUI fatwa in an Islamic banking case trial. Therefore, the existence of this contradiction attracted the interest of researchers to carry out this study. This is because fatwa is not a source of positive laws because it is not stated in the hierarchy of Indonesian laws and regulations as stated in Article 7 of Law No. 12 of 2011. But on the other hand, the form of Perma Supreme Court Regulation No. 14 of 2016 that suspects Islamic principles are incorporated into the court's decision.

In addition, referring to Law No. 21 of 2008 concerning Islamic banking in the general provisions of Article 1 Number 12 mentioned that islamic principles are the principles of Islamic law in banking activities based on fatwas issued by institutions that have authority in the establishment of fatwas in the islamic field relatedto the completion of Islamic economic problems that must use Islamic principles. Therefore, fatwa should be one of the references used by judges in making decisions related to Islamic economic problems in Indonesia. This if continued, it will have an impact that can help the development of Islamic banking institutions in Indonesia. This is because, the development of banking institutions is very dependent on customer confidence in the service products offered [24][25].

Usually people who choose the Islamic approach in economic activity put the belief that fatwa should be the basis for its implementation. But what is worrying, not all judges involved in the trial of 
Islamic banking case make fatwa a consideration in making decisions. The mechanism of resolving Islamic banking cases in the court and consideration of court decisions that have not fully used Islamic fatwas are seen as able to be one of the factors of the failure of Islamic banking institutions in Indonesia in increasing customer confidence in the service products offered.

One of the main keys in maintaining the development of Islamic banking is the legal system that supports the resolution of Islamic banking case. On the other hand, a legal system that does not support the development of Islamic banking in the long term can reduce public confidence in the Islamic banking system, banking credibility and sustainability of economic development [26].

Since the court has been inconsistent in referring to fatwas in taking decisions to discuss Islamic banking cases, this can have an effect on the development of Islamic banking institutions. This is because the Islamic financial system is different from the conventional financial system. The application of sharia law that is inconsistent or uses civil law in talking about Islamic banking situations resulted in a negative effect on the growth of Islamic banking [27]. So is the legal certainty referred to by individuals as well as warring companies that allows for a limp in the Islamic legal system in particular regarding Islamic banking activities.

In addition, referring to Law No. 21 of 2008 on Islamic banking in the general provisions of Article 1 Number 12 mentioned that "Islamic principles are principles of Islamic law in banking activities based on fatwas issued by institutions that have an authority in the establishment of fatwas in the islamic field relatedto the completion of Islamic economic problems that must use Islamic principles".

Therefore, fatwa contained in the OJK regulation should be one of the references used by judges in making decisions related to Islamic economic problems in Indonesia. This if continued, it will have an impact that can help the development of Islamic banking institutions in Indonesia. Even the development of banking institutions is very dependent on customer confidence in the service products offered [28][29]. Therefore, the mechanism of resolving Islamic banking cases in the court and consideration of court decisions that have not fully used Islamic fatwas are seen as able to be one of the factors in the failure of Islamic banking institutions in Indonesia in increasing customer confidence in the service products offered.

\section{Highlights of Work}

\subsection{Islamic Economic Development and Islamic Banking Institutions}

There are several works that discuss the development of Islamic economics and Islamic banking institutions [30]. Is a demanded effort in Islam [31]. Islam wants people to succeed in the life of this world and the hereafter. Elements in the development of Islam are comprehensive and integrated, namely aspects of akhlaq and materiality. While development in the western approach for example in the model of development based on the capitalist system is seen to focus more on material aspects. This model produces pseudo-economic growth (delusion) so that in the moment of the global crisis, the capitalist development system is seen as unable to survive and its impact also affects the public.

Highlights conventional banking institutions, explaining that the percentage of public people's disappetation with global crises is highest in the group of developed countries (Greece, 95\%, Spain, $91 \%$ and Italy, 90\%) and new economies (Lebanon, 93\%, Nigeria, 83\% and Colombia, 82\%). In short, the majority of the population of these capitalist countries feel dissatisfaction with the existing form of the economic system [32].

Western development usually exploits material sources to achieve wealth levels [33]. This is in contrast to the concept of Islamic development which focuses not only on the material aspect but also human development as a whole, including changing people from ignorant communities to Islam. The Islamic approach to development has a philosophy consisting of the concept of tawhid (oneness of Allah), the concept of caliph and the concept of tazkiyyah (sanctity of the soul) [34].

Islamic banking is between the corridors of Islamic finance. The Islamic banking system is the best alternative to people's dissatisfaction with the conventional banking system. Islamic banking has shown great progress over the past two decades and studies show that Islamic banking offers a good and effective financial model [35]. Islamic banking has an important influence in economic development in muslim-majority countries [36].

Islamic banking is seen to guarantee balance in the financial system if executed at its maximum [37]. In Indonesia, Islamic Banking has recorded an increase in funding distributed to communities that have increased capital resources and boosted economic activity [38]. A study in Pakistan found a 
link between economic growth and the development of Islamic banking. In Pakistan the development of Islamic banking has succeeded in supporting the growth of a better financial system as well as supporting the development process [39]. The application of the concept of continuous development is seen to be the answer to improving economic welfare in developing countries that also need to be supported by the development of Islamic banking.

\subsection{Study on the Position of Fatwa}

The position of the National Syariah Council (DSN) fatwa in the national legal system. This study examines the issuance of fatwas by DSN in matters related to Islamic economic activities. The study examines the position of DSN fatwas in the legal system in Indonesia and the extent to which DSN fatwas can be used as a legal reference for judges in religious courts and mediators in the national Shariah Arbitration Body (Basyarnas) [40].

The research method used is qualitative, using interview approach and analysis of legal documents. The results of this study indicate that the judge did not refer to the DSN fatwa as a legal basis in the trial consideration due to its non-binding nature. If the DSN fatwa is used as a legal reference, then the judge and mediator can make the DSN fatwa as a binding law in resolving the case.

The role of fatwas as a legal option to determine the position of residential areas in Singapore either for new forms of property or types of specific or joint ownership rights. This study uses a qualitative method. Conducted by reviewing the Muslim administration law 2009 (Administration Muslim Law Act) Singapore, as well as conducting interviews with experts. The findings of this study conclude that the fatwa must be the main reference in the determination of the position of residential areas in Singapore [41].

From the highlights of the work on the fatwa above it can be concluded that the fatwa has a leading position in various aspects of development involving economic development, development of areas involving land, settlement of international commercial arbitration and distribution of wealth. In fact, the position of fatwa is also seen as practical in both Muslim and non -Muslim countries.

The transformation of the fatwa of the National Syariah Council (DSN) related to Islamic banking into national law, namely Law No. 21 of 2008 on Islamic Banking. This study uses a qualitative method involving the analysis of documents such as the fatwa DSN MUI, Law No. 21 of 2008 related to Islamic Banking as well as various other secondary sources such as journals, newspapers and translations of the Qur'an. There are two important research findings highlighted in this study. First, if the MUI Fatwa (DSN-MUI) is seen within the national legal framework, then the fatwa has no binding legal authority. However, a fatwa can be a binding legal authority if the fatwa is supported by state instruments that have legitimacy, such as Laws, Government Regulations, Bank Indonesia Regulations (PBI), OJK Regulations and so on. Second, Bank Indonesia as the central bank also cannot impose penalties on Islamic banks or Islamic business units that are not based on fatwas. Therefore, the solution is for the fatwa to be made an authoritative law through the transformation of the DSN fatwa into PBI or OJK Regulations with the support of the Shariah Banking Committee (KPS) [42].

A study on the importance of fatwas in improving aspects of shariah compliance was also at three Islamic financial institutions in two countries namely Pakistan and the UAE. The findings of this study recommend the need to control shariah compliance in expanding the Islamic banking market [43]. A framework of shariah governance to ensure shariah compliance in Islamic banking in Oman. that the existence of a framework and basis for the implementation of shariah is a yardstick in achieving Islamic banking standards in Oman [44].

Based on the above study, the position of fatwa in Islamic banking is very important to ensure shariah compliance. In the case of Islamic banking in Indonesia, shariah non-compliance has resulted in conflicts where the cases must be tried in court. However, in Oman, this could be overcome after the enactment of a shariah compliance surveillance law that has successfully reduced Islamic banking conflicts. The highlights of this paper also explain that the position of fatwa is very important in the implementation of Islamic banking operations. Therefore, all institutions (courts, banks or even legislators) should have compliance with the fatwa and this compliance can reduce conflicts in Islamic banking involving the bank and its customers.

Generally, there are 3 main agendas that need to be given attention in advancing Islamic banking namely:

(1) Support by national policy 
(2) The expansion of Islamic economic and financial institutions

(3) Education and cultivating Islamic economic values and concepts.

Islamic principles that must be applied in the settlement of cases. Explain the importance of fatwas in determining the rate of modern financial assets and the need for new interpretations of fatwas in this regard [45]. Is what makes the fatwa important to study as the application of fatwas involving Islamic banking in Indonesian courts.

In conclusion, studies examining the application of fatwas on financial services authority rules in the consideration of judge decisions and their implications on the development of Islamic banking have not been extensively studied. Therefore, this study tries to fill the existing gaps by focusing the scope of the study on the application of Islamic banking fatwas in court decisions as well as its implications on the development of Islamic banking institutions in Indonesia.

The support of Islamic banking-friendly national policies is important to ensure the implementation of operational arrangements and oversight as well as case resolution procedures in court. Thus, the fatwa is based on the literature review, it can be concluded that the banking system is very important in supporting the development of a country. In most countries, especially Muslim majority countries, the banking model that currently exists is divided into conventional banks and Islamic banks [46].

Referring to Figure 1 the court is one of the institutions in resolving disputes in banking cases, including cases involving Islamic banking. In resolving the case of Islamic banking in Indonesia, there is currently a regulation of Law No. 21 of 2008 on Islamic banking. Therefore, the DSN MUI fatwa became one of the principles in resolving Islamic-based cases. Regarding the use of the DSN MUI fatwa in the case of Islamic banking, that is, the DSN MUI fatwa must be enacted into the OJK rules before it can be used by judges. OJK rules related to Islamic banking must be based on the DSN MUI fatwa.

The framework of the study is summarized in Figure 1.

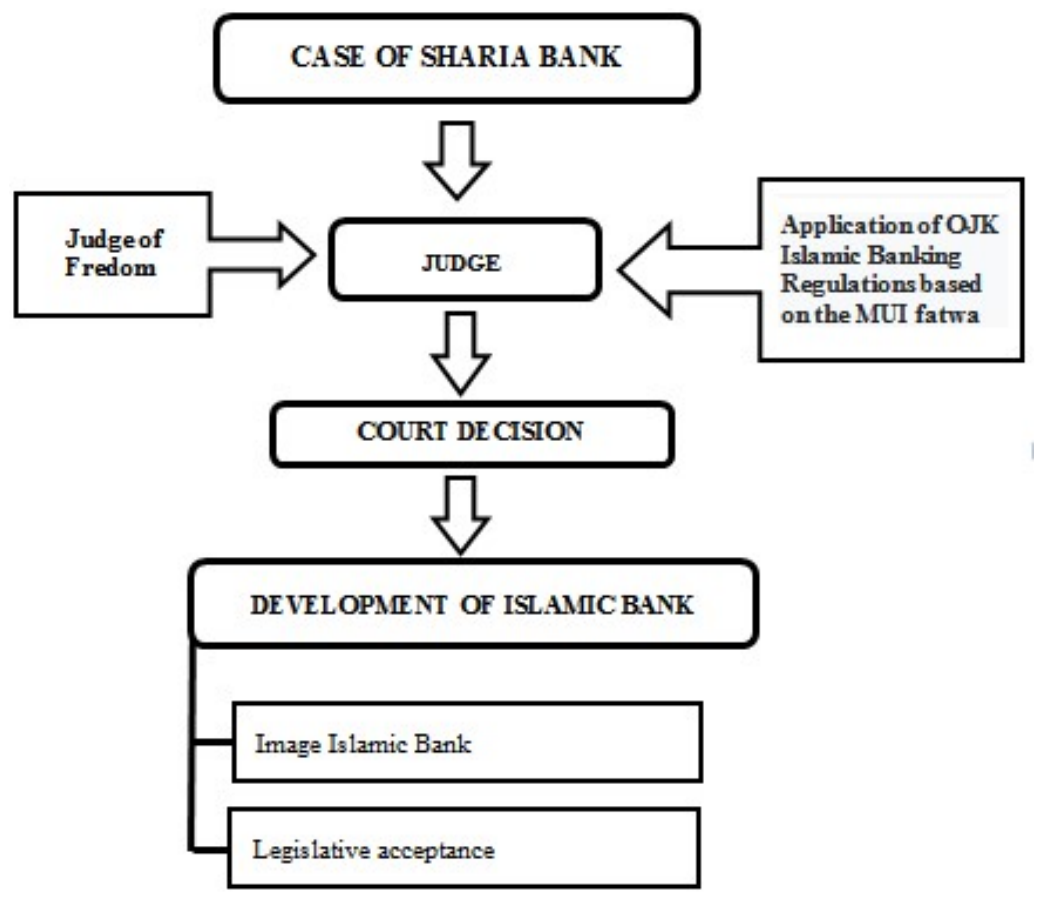

Figure. Research Framework

A court decision is a decision that forms the basis of a settlement for a disputing party. The decision of the court should be in accordance with the law which shows justice and can benefit the disputing parties. The same is true of court decisions involving Islamic banking. The decision should be able to support the existence of a stronger Islamic banking system. This is because, court decisions can affect consumer confidence in Islamic banking, and Islamic banking investors in the Islamic - 
settled financial sector as well as reflect the legal competence in the field of Islamic banking. All of these are central to the development of Islamic banking. The development of a good banking system is one of the most important aspects in driving the development of a country [47].

In general, this study will analyze the application of fatwas in court decisions derived from, Islamic banking law and freedom of judgment on the impact of the development of Islamic banking institutions, in particular to the legal perspective in supporting Islamic banking institutions.

\section{Research Methodology}

The study design is important in order to strengthen the paradigm that will be used in this study. Study design is a plan to determine the research methods used to obtain answers to research problems that have been identified. This design also aims to answer specific research questions that have been constructed.

Although the philosophy of the study is usually hidden, it nevertheless affects the study and is important to identify [48]. There are several philosophies or paradigms of research such as postpositivism, constructivism, organization/participation and pragmatics.

Generally, this study falls into the category of constructivist philosophy i.e. the search for understanding of problems in the environment under study. This understanding is the result of the interpretation of information obtained from open-ended interviews and documents. Generally constructivist philosophy involves inductive qualitative study. The researcher produces meaning or understanding of the results from the data collected from the field of study.

Qualitative studies are study designs that are considered new. Although the term 'qualitative research' was claimed to be rare in the early 2000s [49] found that studies using a qualitative approach were detected to be gaining ground and favored by researchers as early as the 1990s. Qualitative research is research related to a question or statement, not a hypothesis. Qualitative research typically uses questions such as, how, what, and why. Qualitative research involves inductive reasoning to understand a particular situation including an individual's history and experience [50].

This process is repeated to refine the research questions so that clear and accurate questions can be determined. For the purpose of answering the streamlined questions, further data collection needs to be done. Once the theory or concept can be firmly established, the next process is the writing of the findings or conclusions obtained. Respondents in this study include a group of experts, namely: expert in the field of figh, member of the Majlis Ulama Indonesia (Indonesian Ulema Council), expert in Islamic jurisprudence, Islamic advisory council and Islamic banking specialist.

\section{Conclusion}

This study recommend the need to control shariah compliance in expanding the Islamic banking market. The position of fatwa in Islamic banking is very important to ensure shariah compliance. In the case of Islamic banking in Indonesia, shariah non-compliance has resulted in conflicts where the cases must be tried in court. The highlights of this paper also explain that the position of fatwa is very important in the implementation of Islamic banking operations. Therefore, all institutions (courts, banks or even legislators) should have compliance with the fatwa and this compliance can reduce conflicts in Islamic banking involving the bank and its customers. Generally, there are 3 main agendas that need to be given attention in advancing Islamic banking namely support by national policy, the expansion of Islamic economic and financial institutions, and the last is education and cultivating Islamic economic values and concepts.

\section{References}

[1] S. K Hasan, and S. Ahmad, Economic Islam, Second Edition. Kuala Lumpur: Dewan Bahasa dan Pustaka, 2005.

[2] I. S Beik, and L. Dwi, Pembangunan Ekonomi Syariah. Edisi Revisi. Jakarta: PT. Raja Grafindo Persada, 2016.

[3] A. Karim, Bank Islam, Analisis Fiqih dan Keuangan. Jakarta: Penerbit Rajagrafindo, 2004.

[4] A. A. Husain, Ekonomi Islam Prinsp, Dasar dan Tujuan, Edisi Pertama, Yogyakarta: Penerbit Magistra Insania Press, 2004. 
[5] I. Ansori, "The Position of Fatwa in Several Muslim Countries (Malaysia, Brunei Darussalam and Egypt)". Jurnal Analisis, vol. 17, no. 1, pp. 21-30, 2017.

[6] K. Umam, "The Prohibition of Riba and the Application of Islamic Principles in the Banking Law System in Indonesia", Mimbar Undang-undang, vol. 29, no. 3, pp.36-45, 2017.

[7] J. C. Colon, "Choice of Law and Islamic Finance", Journal Texas International Law, vol. 46, no. 3, pp. 411, 2011

[8] G. Dewi, Aspek Hukum Perbankan Islam dan Asuransi di Indonesia. Depok: Penerbit Kencana, 2017.

[9] P. Abedifar, "Risk in The Islamic Banking", Jurnal Review of Finance, vol. 17, no. 2035-2096, 2013

[10] F. Shahzad, "Growth of Islamic Banking in Middle East and South Asian Countries," International Journal of Management, Accounting and Economics, vol. 1, no. 3, pp. 27-39, 2014.

[11] Ikit, Akuntansi Penghimpunan Dana Bank Islam. Yogyakarta: Penerbit Deepublisher, 2015.

[12] Z. Ali, Undang-undang Ekonomi Islam, Jakarta : Penerbit Sinar Grafika Offset, 2008.

[13] Sekretariat Negara, "Undang-Undang Republik Indonesia No. 21 Tahun 2008, 2008 [Online]. Available https://jdih.setneg.go.id/Produk [Accessed: Dec 2,2020]

[14] Z. Arifin, Dasar-Dasar Manajemen Bank Syariah, Jakarta: Penerbit Azkia Publisher, 2009.

[15] H. Juwana dkk, "Sharia Law as a System of Governance in Indonesia: The Development of Islamic Financial Law", Journal Wis Int Law, vol. 25 no. 4, pp.235-242, 2008.

[16] B. Djalil, Mahkamah Agama Di Indonesia (edisi revisi). Jakarta : Penerbit Kencana, 2017

[17] Sekretariat Negara, "Undang-Undang Republik Indonesia No. 21 Tahun 2011, 2011 [Online]. Available https://jdih.setneg.go.id/Produk [accessed: Dec 2,2020]

[18] Ruslaini, "Ijtihad Hakim Dalam Menyelesaikan Kes Ekonomi Islam Dilingkungan Peradilan Agama", Jurnal Jurnal Ekonomi Islam, vol. 8, no. 2, pp. 19-34, 2017.

[19] A. Suadi, Penyelesaian kes Ekonomi Islam. (Edisi Revisi). Depok : Penerbit Kencana, 2017.

[20] A. Suadi, Penyelesaian Kes Ekonomi Islam (Penemuan dan Kaidah Undang-undang). Jakarta : Penerbit Prenadamedia Group, 2018.

[21] R. D. Yona, "Penyelesaian Kes Perbankan Islam di Indonesia". Jurnal Ekonomi dan Undangundang Islam, vol. 4, no. 1, pp. 97-105, 2014.

[22] U. Basuki, "Dinamika Bank Syari'ah dalam Percaturan Perekonomian dan Hukum di Indonesia," Jurnal Az Zarqa, vol. 9, no. 2, pp.123-135, 2017.

[23] F. Sidiq, "Analisis Putusan Mahkamah Terhadap Penyelesaian Undang-undang Ekonomi Islam (Studi Kasus Putusan PA Madiun No. 0403/Pdt.G/2014.Pa.Mn)”, 2013

[24] M. N. Madjid, "Nuansa Konvensional Dalam Perbankan Syariah," Jurnal Nalar Fiqh. Vol. 3, no. 1, pp. 23-41, 2011.

[25] Ismail, Perbankan Syariah. Jakarta: Penerbit PT Prenadamedia Group, 2011.

[26] B. Nasution, Penataan Sistem Hukum Yang Efektif Dalam Mendukung Perkembangan Perbankan Syariah, Makalah dalam Seminar OJK pada hotel JW Marriot Medan, 2015.

[27] R. Grassa and K. Gazdar, "Law and Islamic Finance: How legal origins affect Islamic finance development?," Journal Boursa Istanbul. Vol.12, no.7, pp. 78-85, 2014.

[28] A. M. Alemu, "Factors Influencing Consumers' Financial Transactions in Islamic Banks Compared with Conventional Banks: Empirical Evidence from Selected Middle-East Countries with a Dual Banking System". Jounal African and Asian Studies, vol. 11, no. 12, pp. 444-465, 2012.

[29] A. R. Marzoqi, the Role of Islamic Finance in Economic Development. In: Atbani F.M., Trullols C. (eds) Social Impact Finance. IE Business Publishing: London, 2014

[30] O. R AlJayyousi, Islam and Sustainable Development: New Worldviews, Turkey: Gower Publishing, 2012.

[31] A. Saeed. Bank Islam dan Bunga : Studi krisis Larangan Riba dan Interpretasi, Yogyakarta: Pustaka Pelajar, 2008

[32] A. Wangsawidjaja, Pembiayaan Bank Islam. Jakarta: PT. Gramedia Pustaka Utama, 2012.

[33] F. Khan, Esai-esai Ekonomi Islam. Depok: Penerbit Rajagrafindo, 2014.

[34] N. El Ghattis, "The Futures of Islamic Banking in the Gulf Cooperation Council (GCC)". Journal of Futures Studies, vol.18, no. 4, pp27-44, 2014. 
[35] P. Adam, Fatwa-fatwa ekonomi Islam (Konsep, metode dan Implementasinya pada Lembaga Keuangan Islam). Jakarta : Penerbit Amzah, 2018.

[36] S. Ansari, "The Role of Islamic Banking Industry in the economic Growth of Pakistan," SSRN Journal, vol. 10, no. 21, pp. 231-238, 2013.

[37] N. I. Sitepu, "Peran Bank Syariah Dalam Pengendalian Harga (Studi Analisis Terhadap Perbankan Syariah Di Indonesia)," Jurnal Perspektif Ekonomi Darussalam, vol. 1 no. 1, pp. $25-$ 35, 2015.

[38] S. L. Ayyubi, "Pengaruh Bank Syariah Terhadap Pertumbuhan Ekonomi Di Indonesia," Jurnal Al-Muzara'ah, vol. 5, no. 2, pp. 95-102, 2017.

[39] M. S. Sarwer et al, "Does Islamic Banking System Contributes to Economy Development," Global Journal of Management and Business Research, vol. 8, No. 2, pp. 23-35, 2013.

[40] T. N. Cahyadi, "Penyelesaian Kes Perbankan Islam," Jurnal Ekonomi Islam, vol. 1, no. 2, pp. 123-132, 2011.

[41] M. B. Hooker, "Succession to Muslim Estates in Singapore: Sources of Law and Choice of Law," Australian Journal of Asian Law, vol. 15, no. 2, pp.1-34, 2014.

[42] Mardani, Aspek Undang-undang Lembaga Keuangan Islam di Indonesia (Edisi Pertama). Jakarta: Penerbit Kencana, 2015.

[43] S. Ullah, "Fatwa Repositioning': The Hidden Struggle for Shari'a Compliance within Islamic Financial Institutions," Journal Bus Ethics, vol. 14, no.5, pp.895-917, 2018.

[44] M. I. Mihajat, "Shari'a Governance Framework in Islamic Banking in Oman: Issues and Challenges," Journal of Islamic Banking and Finance, vol. 5, no. 8, pp. 99-121, 2018.

[45] A. E. Taha and Sohaib, "Charity Disparity: The Challenge of Applying Religious Law on Zakāt in the United States," Journal of Law and Social Policy University School of Law, vol. 14. No.12, pp. 67-88, 2018.

[46] Trisadi, and A. Somad, Undang-undang Perbankan, Jakarta: Penerbit Kencana, 2016

[47] Todaro, and S. C Smith, Economic Development, twelf edition. New york: Penerbit New york University, 2015.

[48] Creswell, Research Design: Qualitative, Quantitative and Mixed Method Approach. California: SAGE Publications, Inc. 2455 Teller Road Thousand Oaks, 2014.

[49] H. T. Wolcott, Writing up qualitative research (3rd Ed.). California: Thousand Oaks, CA: Sage, 2009.

[50] T. William, the Research MethodsKnowledge Base, $2^{\text {nd }}$ Edition, USA: Atomic Dog Publishing, 2006. 